\title{
Case of study: The windmill of el pasico: Alive cultural heritage
}

\section{Caso de estudio: El molino de viento de el pasico: Patrimonio cultural vivo}

DOI: $10.46932 / \mathrm{sfjdv2n5-104}$

Received in: Oct 1st, 2021

Accepted in: Dec 30th, 2021

\author{
José Antonio Martínez-Pando \\ Degree in Social and Cultural Anthropology (UNED) \\ Social Sciences (Anthropology) PhD student (UCAM) \\ UCAM (Universidad Católica de Murcia) \\ Av. de los Jerónimos, 135, 30107 Guadalupe de Maciascoque, Murcia \\ E-mail: ppcart@hotmail.com
}

\section{RESUME}

The Campo of Cartagena counts on an excellent rural heritage not only for its monumental and landscaping values but also for its material and immaterial heritage. Of all of these monuments, the windmill of El Pasico highlights for its wonderful state of conservation, for being a symbol of its proud town and for being a cultural, touristic and leisure resource.

Keywords: Windmills, Rural Heritage, Campo de Cartagena, Industrial Heritage, Social Anthropology

\section{RESUMEN}

El Campo de Cartagena cuenta con un excelente patrimonio rural no sólo por sus valores monumentales y paisajísticos sino también por su patrimonio material e inmaterial. De todos estos monumentos, el molino de viento de El Pasico destaca por su magnífico estado de conservación, por ser un símbolo de su orgulloso pueblo y por ser un recurso cultural, turístico y de ocio.

Palabras clave: Molinos de viento, Patrimonio rural, Campo de Cartagena, Patrimonio industrial, Antropología social

\section{INTRODUCTION}

The geographical area of Campo of Cartagena was once densely populated by windmills which were used to grind cereals, salt and to get water from beneath the soil. Those machines became useless due to the sudden overcome of power and combustion engines: what was an essential tool in everyday life became a relic of older times. Their abandon has led them to ruin in most of the cases.

Just a few of them are still standing. This is thanks to public funds that subsidise the owners and public entities to recuperate them. Nevertheless, the immense majority of them are in an appalling state and dozens of them have already disappeared 
However, the Asociación de Molinos de Torre-Pacheco, with the inevitable help of the Town Hall of this town, work in unison to maintain these buildings, its tradition and give them a use as a touristic asset.

Of all of these windmills, the case of the windmill of El Pasico is unique. This windmill is open to the public and is carefully maintained with it original structure, although some elements needed to be reincorporated due to their disappearance or bad state, especially parts of its wooden machinery.

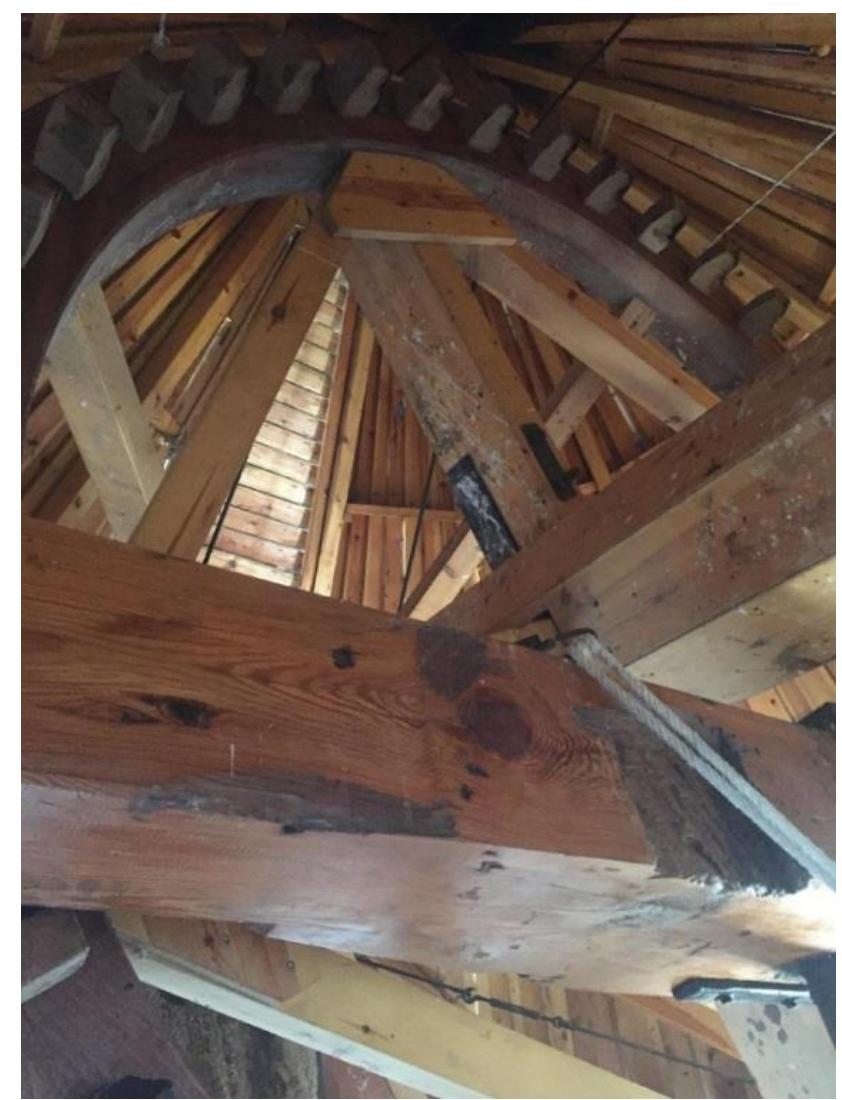

Besides, it is frequently used as a touristic attraction very popular among the inhabitants of the town, people of nearby towns and holidaymakers from coastal and golf resorts.

Despite the phenomenal tangible and intangible heritage, the public institutions have not been able to promote its importance to the owners that have inherited them and see them as a nuisance in the middle of their extremely productive lands dedicated to a very valued intensive agriculture that export millions into EU countries (Luján Ortega, García Martínez, 2007).

What used to be a rural self-subsistence life has become a factory vegetable-maker way of production, thanks to the water coming from the canal Tajo-Segura which has transformed completely the economic intake but also the whole society and its customs. (Román Cervantes, 2004).

The recent meetings of experts in rural industrial heritage and the biannual organisation of Congreso Internacional de Molinología have given the windmills a new interest for the general public. 
As a good example of it, it can be mentioned the latest XII Congreso Internacional de Molinología that took place in Alcalá de Henares in November 2021.

\section{THEORICAL FRAMEWORK}

Just behind the city of Cartagena that counts on 152 windmills, it is the town of Torre-Pacheco that second with a higher number of these giants in their lands.

The town of Torre-Pacheco has a total of fourteen windmills; eight are for grinding cereals and six for water supply. All of them have been considered as elements under protection (Bien de Interés Cultural $^{2}$ ) regardless of their state of conservation. All the windmills of Campo de Cartagena are included in the Red Book from the UNESCO dedicated to heritage endangered to extinction ${ }^{3}$.

The water supply from the canal of Tajo-Segura brought a profound agro-industrial change which led to even sharper economic and social changes (Martínez Menchón, Melchor Sennet 2007). Groups like Asociación de los Molinos de Viento de Torre-Pacheco have promoted the protection and conservation of windmills as an industrial and cultural heritage (Sánchez Conesa, 2008).

The traditional agricultural practices have been overtaken by the new technologies and together with this, traditions and customs have been modified (Aguilar Rocha, Irving Samadhi, 2021). This leads to a change in the identity of the dwellers and due to this in the whole social structure of the society.

windmills that inhabit the region, there is no other like the windmill of El Pasico. Being the only one that keeps its full wooden machinery, it still works as it used back in the XIX century. This windmill has become the most significant cultural symbol for the town of Torre-Pacheco.

The main characteristic of the windmills in Campo de Cartagena are their sails that have the same shape of a sail of a Latin sail boat.

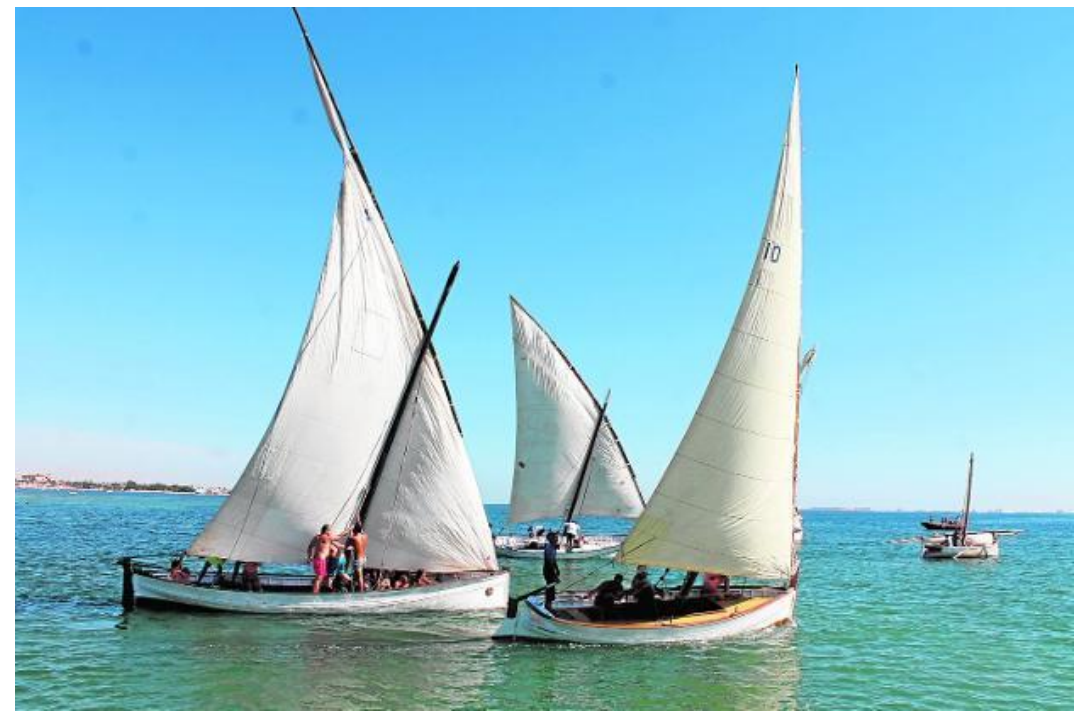


Despite of other towns in the surrounding that have an important patrimonial heritage or are sited very near from the sea, the town of Torre-Pacheco have very little patrimonial assets to become a touristic town. This is the reason why the windmills have become for this town a key aspect of their idiosyncrasy. Most of its inhabitants feel proud of their windmills especially of those that are placed in the middle of the town.

This interest for the windmills have made that they are present everywhere in the town. There is a playground for children in which the main attraction is a slide with the shape of a windmill.

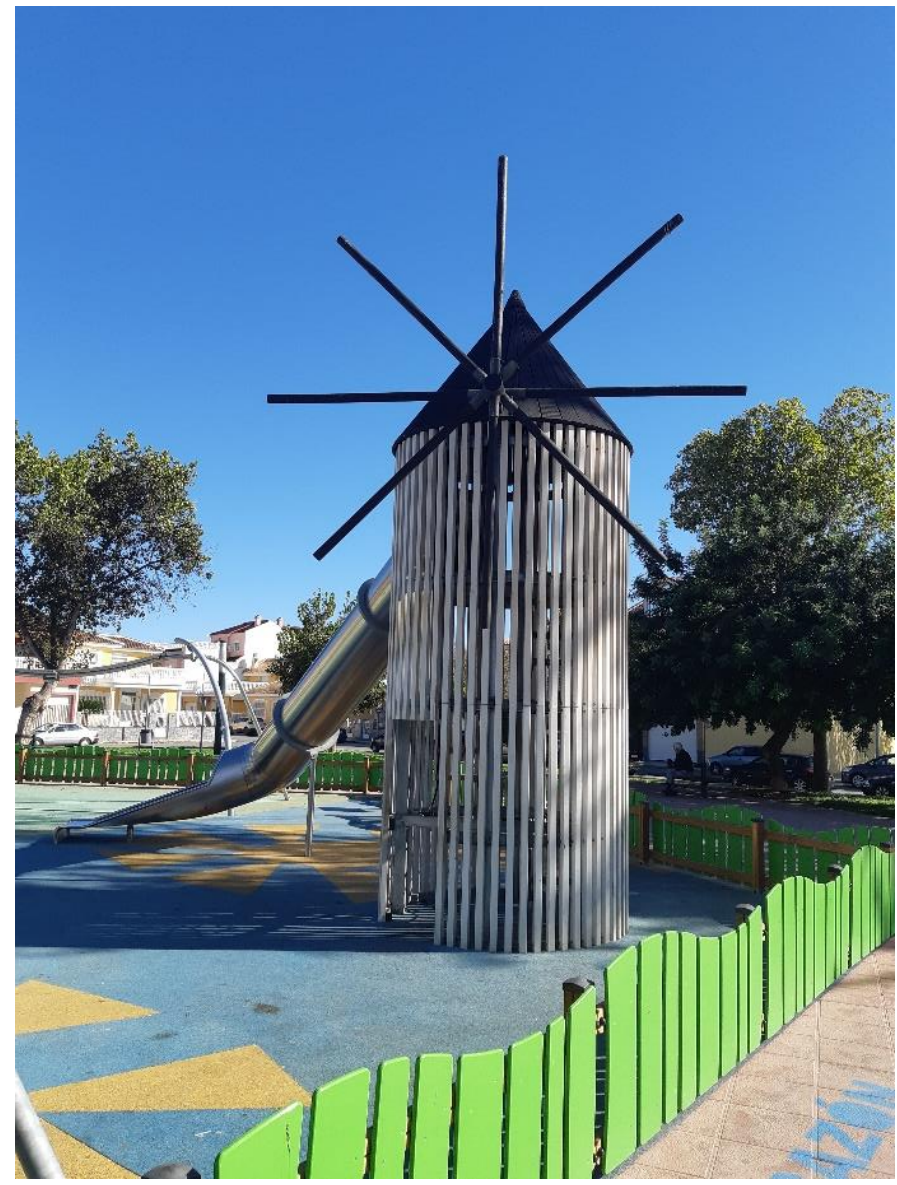

Every road that leads to Torre-Pacheco shows a sign with a windmill painted on it. These are just two examples of how the presence of the windmills is mixed with the everyday tasks of these dwellers. 


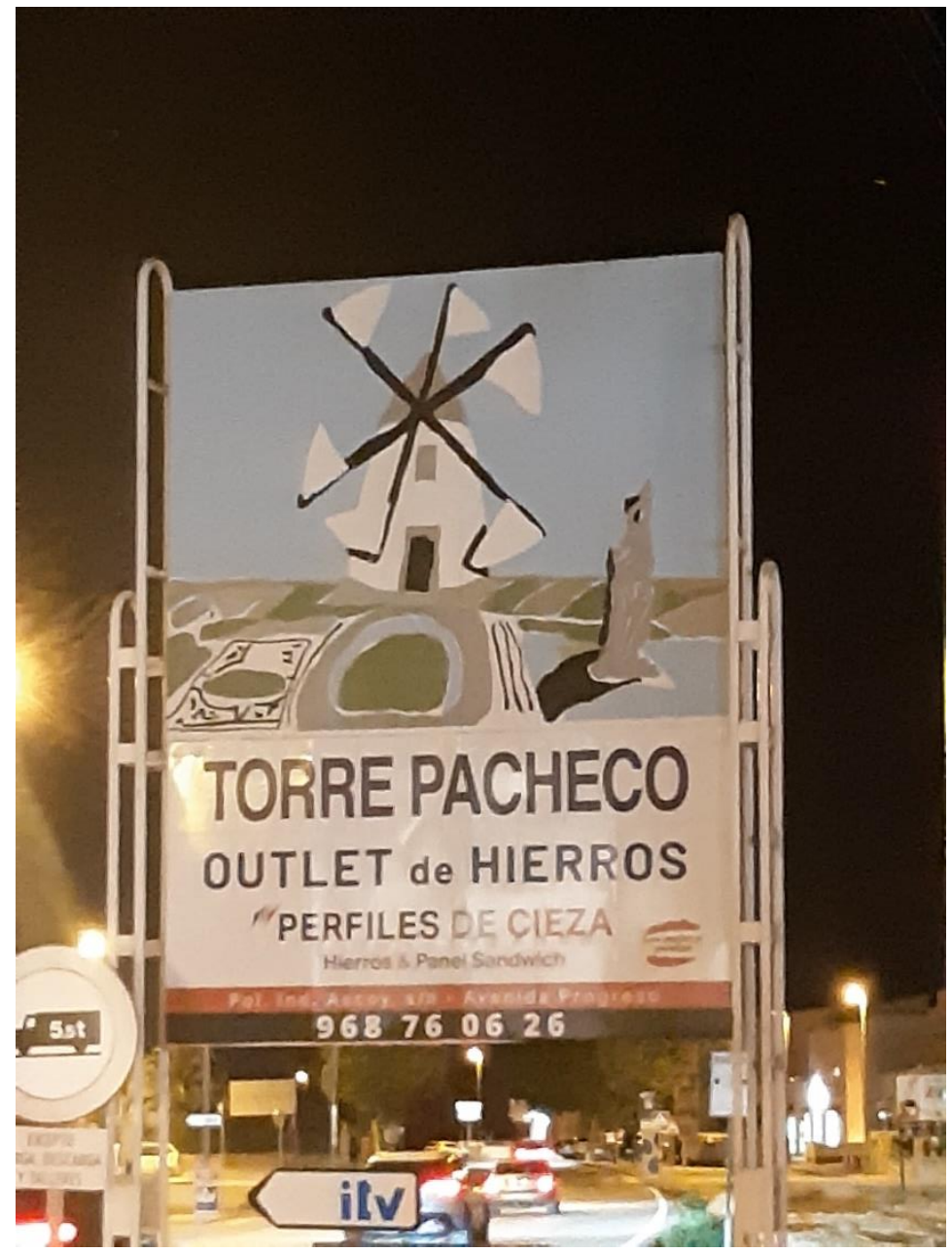

Most surely the windmill of El Pasico could be the only one that has a musical event annually. The wind orchestra, Union Musical de Torre-Pacheco, celebrates a concert in July, with great enthusiasm from public, since 2017.

This event is hugely celebrated in the whole town because the Town Hall provides all the elements to celebrate the concert at the same time that they provide the possibility to a theatrical visit with actors dressed up as millers. All this, while the windmill is grinding cereals, the tourist guide explains the history, society and functions of the windmill.

This event has been cancelled during the last two seasons due to the pandemic of Covid-19. 


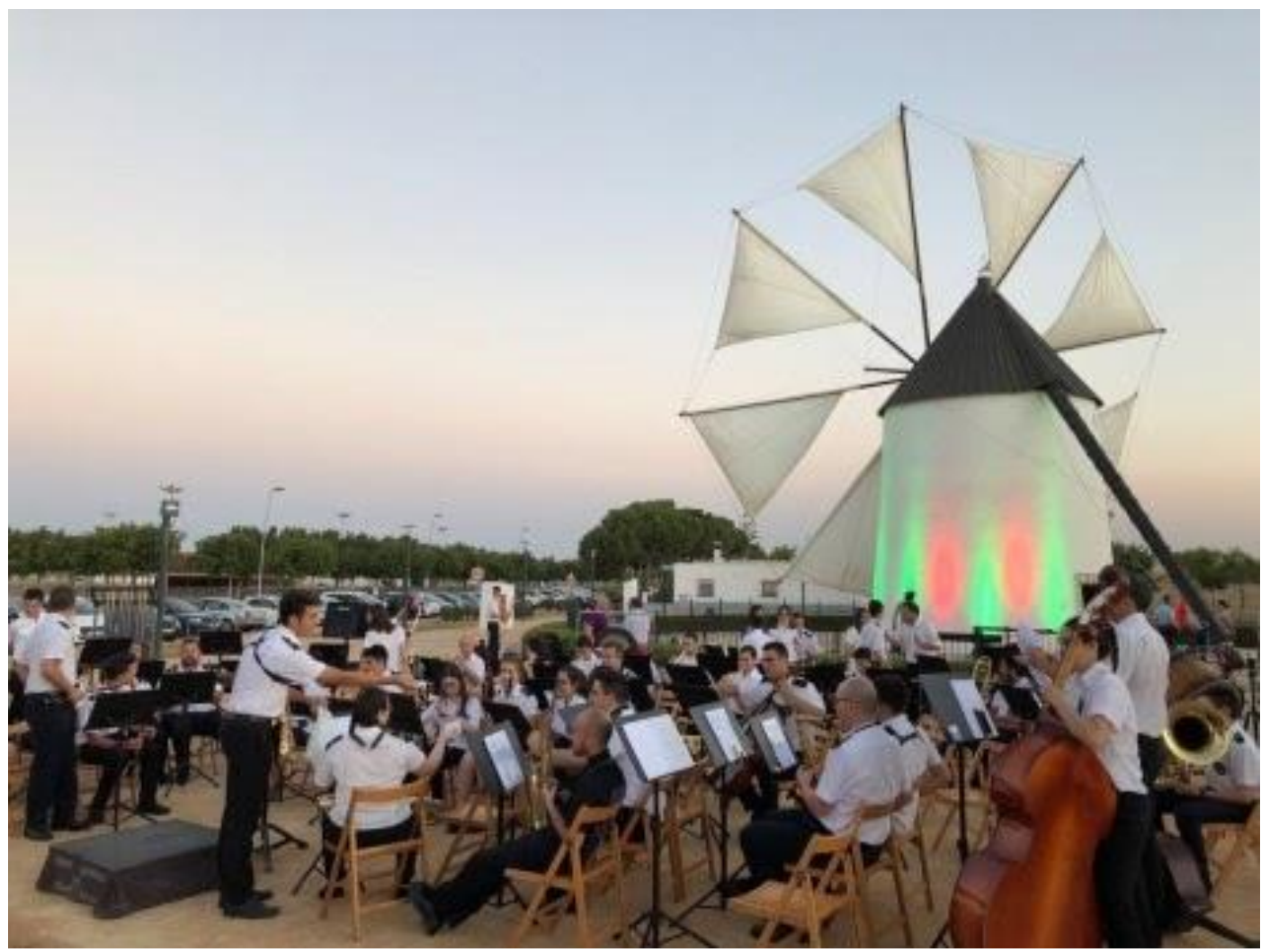

Although it was also cancelled during the pandemic, the Romería of San Miguel which is celebrated on the same date that the Fiesta de los Molinos, by the end of September is a means of promoting the windmills and the rural customs currently disappeared. These celebrations were created by the Asociación de Molinos de Torre-Pacheco. and it gathers a mixture of traditional food, music, clothing... a combination of tradition and heritage that is very welcome by the people present.

Also, it is important to highlight the case of the Dutch Kinderdijk ${ }^{7}$, which was declared by the UNESCO as World Heritage. This consists of nineteen windmills in perfect state of conservation that are the most important touristic attraction in The Netherlands. If this have been achieved there, it is an example to follow and consider that taking care of the local heritage is also a good means of promotion and business.

\section{METHODOLOGY}

The methodology used for this piece of research is based on qualitative methods being the interview and the participant observation the most used ones.

Besides, the Town Hall of Torre-Pacheco promotes several events at the windmill which is also center of exhibitions for locals and foreigners interested in windmills. 
On the one hand, Mr. Pepe Nieto, the miller, and the tourist guide from the town hall has given profound explanations of the functions of the windmill.

On the other hand, it has been possible to talk about the thoughts of the visitors to the windmill through informal conversations that are full of different opinions from local and foreigners.

Also, there are acts that occur every year as the Romería of San Miguel that takes place every $29^{\text {th }}$ of September and these events have also been used to gather information.

This event is rather significate because it is not only centered in the windmill but also in traditional food including wine, desserts and ancient folk music.

It is worthy to remind that all these events were called off for two years due to the pandemic, Covid-19

\section{CONCLUSIONS}

1. - It is proposed to maintain and promote activities like the Fiesta de los Molinos and Romería de San Miguel which supposes a loudspeaker to raise consciousness about heritage protection, apart from empowering all the other activities attached to it such as popular games, popular dance and music, peasants' gastronomy, liturgical acts, etc.

2. - With no doubt, the most remarkable act due to the fact that it is unique, is the music festival celebrated yearly. It is proposed to continue with its celebration which carries a great assistance of public, visits to the windmill and awareness about the past cultural heritage, as well as the nowadays and past music culture.

3. - It is proposed to study the phenomenon of Kinderdijk $\mathrm{k}^{8}$ in Holland that has made that a group of windmills has become one of the most important touristic spaces not only in Netherlands but in the whole European continent. For this, the recovery of all the windmills should be an essential must for politicians and owners.

4.- It would be advisable to study the industrial use of these constructions for those persons who aim to go back to a more natural life. However, this can only be done after the approval of the Food Security authorities.

5. It is proposed to work on the possibility to use the monument as a rural hotel for short stay that it is estimated that it would become of great interest for locals and visitors to the nearby coastal towns 


\section{BIBLIOGRAPHY}

1) LUJÁN ORTEGA, María; GARCÍA MARTÍNEZ, Tomás (2007):” El patrimonio de la cultura del agua en el paisaje del Campo de Cartagena.” en Revista Murciana de Antropología, núm 14, pp 567602.

2) Web of record of heritage declared as BIC belonging the Autonomous Community of Region of Murcia: http://www.patrimur.es/web/patrimonio-cultural/bienes-de-interes-cultural1

3) https://listarojapatrimonio.org/ficha/molinos-de-viento-del-campo-de-cartagena/

4) SÁNCHEZ CONESA, José (2008): "La asociación de molinos de viento de Torre-Pacheco. Un nuevo folklore para la recuperación del patrimonio." en Revista Murciana de Antropología, núm 15, pp 267-282.

5) MARTÍNEZ MENCHÓN, Marina; MELCHOR SENENT, Alonso (2007): "El agua en el Campo de Cartagena." en Revista Murciana de Antropología, núm 14, pp 47-61.

6) ROMÁN CERVANTES, Cándido (2004): “Ciento cincuenta años de transformaciones agrarias en la comarca del Campo de Cartagena: del sistema cereal a la especialización hortofrutícola" en Revista Murciana de Antropología, núm 14, pp 81-98.

7) Web regarding patrimonial heritage of kinderdijk en The Netherlands: https://www.kinderdijk.com/discover/the-story/

8) Web regarding patrimonial heritage of kinderdijk en The Netherlands:

https://www.holland.com/global/tourism/destinations/provinces/south-holland/the-windmills-o

9) Aguilar Rocha, Irving Samadhi (2021) “La ciudad contemporánea: Identidad y patrimonio” South Florida Journal of Development, Miami, v. 2, n. 4, jul./sep. 2021 p.6160-6168. 